DIPLOMA OF WHITENESS 



\author{
Jerry Dávila
}

\title{
DIPLOMA OF WHITENESS
}

Race and Social Policy in Brazil, I917-1945

DUKE UNIVERSITY PRESS DURHAM \& LONDON 2003 
(C) 2003 Duke University Press All rights reserved

Printed in the United States of America on acid-free paper $\infty$ Designed by Rebecca M. Giménez Typeset in Quadraat by Keystone Typesetting, Inc. Library of Congress Cataloging-in-

Publication Data appear on the last printed page of this book. 
FOR LIV 
